\title{
Tebakak Leaves Plates as an Eco-friendly Disposable Plates: Cultural Roots, Technology and People Transformations
}

\author{
Martinus Martinus 1,* Gita Paramita Djausal ${ }^{2,}$ Sri Ratna Sulistiyanti ${ }^{3,}$ \\ Meizano Ardi Muhammad ${ }^{3}$, Mareli Telaumbanua ${ }^{4}$
}

\author{
${ }^{1}$ Mechanical Engineering Department, Engineering Faculty, Universitas Lampung \\ ${ }^{2}$ Business Administration Department, Social and Political Science Faculty, Universitas Lampung \\ ${ }^{3}$ Electrical Engineering Department, Engineering Faculty, Universitas Lampung, Jl. Prof. Soemantri Brojonegoro, \\ Bandar Lampung 35145, Indonesia \\ ${ }^{4}$ Agriculture and Bio System Engineering Department, Agricultural Faculty, Universitas Lampung, Jl. Prof. \\ Soemantri Brojonegoro, Bandar Lampung 35145, Indonesia \\ *Corresponding author. Email: martinus@eng.unila.ac.id
}

\begin{abstract}
Plastic has become the dominant problems in recent years since it become the dominant material for food packaging. More than 600 thousand tons of plastic becoming waste in 2019. Leaf as food packaging material has been known since the dawn of civilization In Indonesia itself leaf and other plant's organic material commonly used as traditional food wrapper. Commonly known leaves such as banana leaf, waru leaf, tepus leaf, simpur leaf, syzygium leaf and also tembakak leaf are used for wrapping traditional food. Thus triggering for the use of environmentally friendly tebakak leaf plates that are easily biodegradable, easy to produce, hygienic, and have lampung cultural background. One main question can the consumer shift from plastic based disposable plate to greener leaf base plate. Can tebakak leaf plate as an eco-friendly product try to replace plastic or just another plastic alternative. And, the consumer's perspective of tebakak leaf plates as an eco-friendly product. We learn that both leaf plates (tebakak leaf plates and teak leaf plates) can be contender for plastic plates and paper plates while styrofoam plates has the lowest value. The consumer agrees that tebakak leaf plates and the teak leaf plates are green and want to use them. The main hindrance of using the leaf plates is the availability on the market and its higher price.
\end{abstract}

Keywords: Leaf plate, Tebakak, Disposable plates, Eco-friendly

\section{INTRODUCTION}

Plastic has become the dominant problem in recent years since it became the dominant material for food packaging since its mass production in the 1930s[1]. Even in the pandemic year, the plastic waste remains growing while the cities lock down [2].

Leaf as food packaging material has been known since the dawn of civilization [3]. In Indonesia, leaf and other plant's organic material commonly used as traditional food wrapper [4][5] Commonly known leaves such as banana leaf, waru leaf, tepus leaf, simpur leaf, syzygium leaf and also tembakak leaf used for wrapping traditional food.

The reason for developing this Eco-friendly tebakak leaf plate product is the need for disposable plates. Disposable plate is useful in saving time because it does not need to be washed and can be disposed of after use and is easy to use. The need for the leaf plates to be biodegradable so that it can reduce the use of single-use plastic plates and Styrofoam. Indonesia ranks 2 nd in the world as the largest contributor of plastic waste to the ocean after China [6]. In addition, the Indonesian people have long used leaves as food containers, thus triggering the use of environmentally friendly tebakak leaf plates 
that are easily biodegradable, easy to produce, hygienic, and have a Lampung's cultural background.

One main question can the consumer shift from plastic based disposable plate to greener leaf base plate. Can tebakak leaf plate as an eco-friendly product try to replace plastic or just another plastic alternative. How consumer react the tebakak leaves plates from organoleptic point of view. And, how the consumer's perspective of tebakak leaf plates as an eco-friendly product.

\section{METHODOLOGY}

One of main assessment for the transformations of consumer behaviour is an organoleptic assessment. Organoleptic research methods are to find and quantified the quality of a product using human senses. These senses are visual sense, olfactory sense, tactile sense, taste sense, auditory sense. Even though it is quite often that method of carrying out organoleptic research usually called tasting. But it is far more complex than just taste. In this case a variety of organs participate in the process. Which are taste bud, tactile sense, visual sense and smell or olfactory sense. Perspective assessment is also done to find how consumer perspective toward an ecofriendly product. This perspective is the key how an ecofriendly product will move forward.

The assessment is done from 20 young adult respondents. These respondents are all college educated person. We hope that these respondent will shape Indonesia future consumer[7][8]. And these responders are representing Indonesian perspective towards ecofriendly product.

There are five disposable plates in review. Two comes from ecofriendly product which are tebakak leaf plate and teak leaf plate. The other three are plastic plates, Styrofoam plates and paper with hdpe lamination plates. All of the plates is shown and used by the respondents. These respondent then will score how each plates perform. There are six question with 1 to 5 grade value for each question. In short, the questions are: is it changing taste; how is the appearance; how is the texture; how is the smell; is it green; and do you want to use it on regular basis. We also look the strength and the weaknesses of the disposable product.

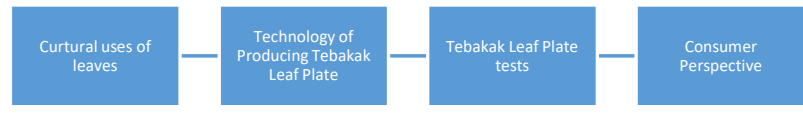

Figure 1. Leaf Plates Assessment Process

\section{RESULT AND DISCUSSION}

\subsection{The Culture of Natural Packaging}

Indonesia consists of more than a thousand three hundred ethnic diversities with its own unique culture[9]. The culture includes the traditional structures, traditional wisdoms, traditional customs, food and arts and many more[10]. Among all of the diversity, one common unique culture is its unique traditional foods[11], in conjunction to food is the technology to process the food and also the packaging to serve the food[12].

Each and any tribes in Indonesia has its unique type, process, and traditional food packaging. The existence of traditional food in general cannot be separated from the customs in cultural society. So that traditional leafy container as packaging of traditional food can be reflection of the culture of a society. Packaging culture actually started since humans know how to store and serve food. Serving and storing of food traditionally begins by keeping food in a container which he found. The container can be leaf, husk, bamboo column, Coconut shell, shell and even woven material from natural fiber they found in their culture. Along with the times the container becoming more complex, and has many cultural values. The use of leaves as food wrappers is to beautify the appearance of food, as well as adding a distinctive aroma and delicacy of food[13].

Natural packaging materials are still used in almost all regions of Indonesia on daily basis[14]. Because it is usually very cheap, readily available and not have a negative impact against environmental and will be naturally decomposed. In this case, the function of packaging as an identity is absolutely considered. However, the uniqueness of traditional packaging cannot be replaced.

\subsection{Tebakak Leaf Plates}

Tebakak leaf as raw materials are widely available naturally, currently leaves is not used commercially, so it is available quite abundant. Tebakak (Ficus septica) is a fast growing tree with seeds dispersed through rain water. The tree grows very fast with very wide leaves. The tree is soft wood tree usually unused because of the low quality of the wood. Tebakak (Ficus septica) traditionally used by the people of Lampung as a food wrapper. The alkaloids found in Ficus septica leaves have cytotoxic effects on cancer cells[15].

Environmentally friendly tebakak leaf plates made from Lampung tebakak leaf are an alternative to disposable plates. Tebakak leaf plates are biodegradable, easy to produce, hygienic, and have long period of storage time. The Lampung tebakak leaf material is a local wisdom from the Lampung area. Plate 
production is quite easy and economical because it only changes the shape of the leaves to follow the shape of the plate. The tebakak leaf plate has the integrity of the leaf structure so that the strength and characteristics of the leaves are maintained. The leaf plate has a diameter of $22 \mathrm{~cm}$ with a plate indentation depth of about $3 \mathrm{~cm}$ and is able to accommodate relatively large amounts of food (357 grams). Tebakak leaves are hot molded processed with natural adhesives from starch so they are more durable. Tebakak leaf plates can be stored for more than 6 months.

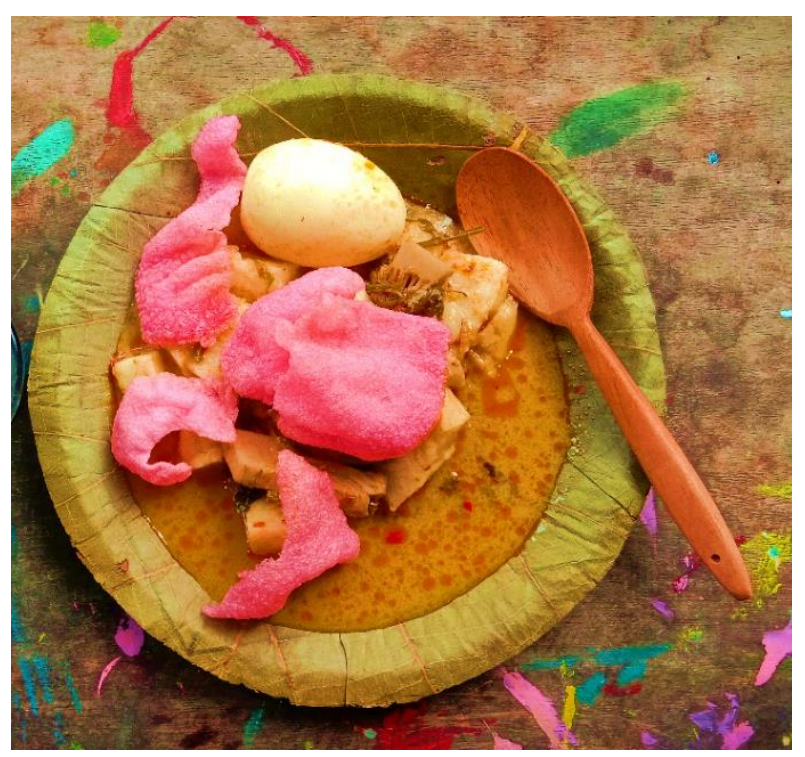

Figure 2.Tebakak leaf plate used to serve lontong sayur a local delicacy

The Lampung tebakak leaf used is local wisdom because it is a typical plant from the Lampung region which has distinctive leaf characteristics in its motifs Table 1. Product Comparison and textures. These qualities provide additional selling points, apart from being biodegradable, for prestige and environmental concern. The resulting product has a low water content so that it can be stored for a long time. This is possible through a leaf molding machine that uses a molding press with a temperature controlled heating element.

Some of the characteristics of the machine for the production of leaf plates are precision pressure, temperature control, and plate mold adapting to the leaf structure. The Lampung tebakak leaves are used because of their strong structure, wide cross-section, and distinctive leaf characteristics. This innovation can make a substitute product for plastic plates and Styrofoam to overcome the bad impact of plastic and Styrofoam on the environment (plastic decomposes takes more than 100 years, while styrofoam does not decompose[16]).

The advantages of tebakak leaf plate products are:

1. Using the natural ingredients of Lampung local wisdom, namely the Lampung tebakak leaf.

2. Using leaf natural structure for its strength and waterproofness so that it is easy to produce.

3. Made of organic material so that it is easy to decompose in the soil and is environmentally friendly.

4. Free from chemicals.

The disadvantages of environmentally friendly leaf plate products are:

1. Leaf plates do not last long if exposed to water for a long period of time.

\begin{tabular}{|c|c|c|c|c|}
\hline Aspects & Leaf Plates & Plastic Plates & $\begin{array}{l}\text { Styrofoam } \\
\text { plates }\end{array}$ & Paper Plates \\
\hline Market price & Rp. 1500,- & Rp. 1,000,- & Rp. 500,- & Rp. 1,000,- \\
\hline Shelf time & 6 months & 5 years & 5 years & 2 years \\
\hline $\begin{array}{l}\quad \text { Natural } \\
\text { Decomposition } \\
\text { Time }\end{array}$ & 2-4 weeks & $100-200$ years & $\begin{array}{l}\text { More than } 500 \\
\text { years }\end{array}$ & $\begin{array}{l}\text { Paper decompose in } 1 \text { Month } \\
\text { but the plastic lamination will } \\
\text { decompose in } 100 \text { years }\end{array}$ \\
\hline Waterproof & Yes & yes & yes & yes \\
\hline Heat Resistance & Good & Not good & best & good \\
\hline $\begin{array}{l}\text { Raw material } \\
\text { available locally }\end{array}$ & Yes & no & no & partial \\
\hline $\begin{array}{l}\text { Machine } \\
\text { capacity }\end{array}$ & Low & high & high & high \\
\hline
\end{tabular}




\subsection{Tebakak Leaf Plates Machine}

The machine is developed since 2017 for producing leaf plate. It is a manual machine that can be easily replicated for scale up purposes. The machine using a hot press molding to mold the tebakak leaf into plates[17]. It is using two 350-watt heating elements. The temperature is controlled using a PID controller (Proportional Integral and Derivative controller) to achieve 1-degree accuracy. The accuracy is needed as a charred leaf plate is not desirable. Below shown the leaf plate molding machine.

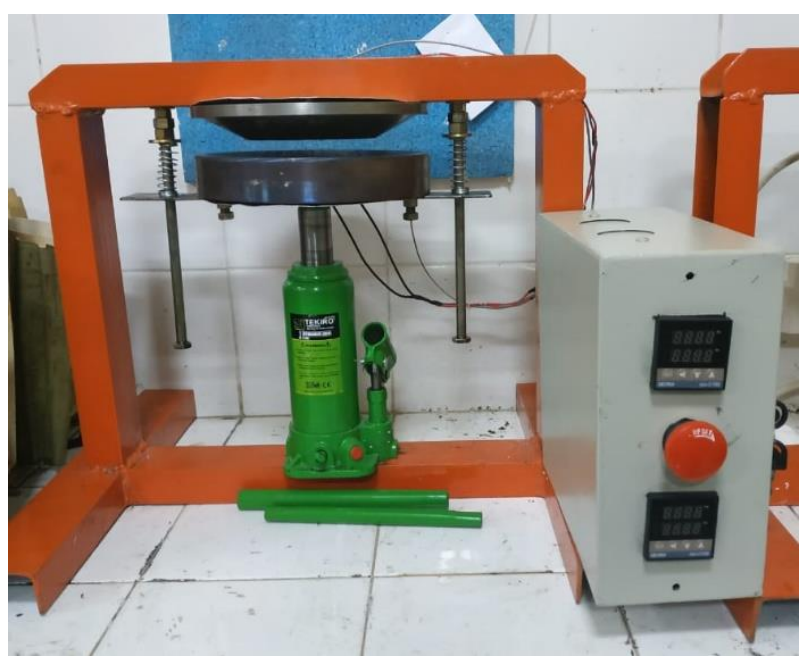

Figure 3. Leaf Plate Molding Machine
The process of making environmentally friendly leaf plates made from lampung tebakak leaves using a leaf plate molding machine, sterilizer, and raw materials tebakak leaves. The tebakak leaf plate production process begins with the preparation of raw materials, tebakak leaves. Fresh leaves then cleaned through washing and drying. After that, the layering out the leaves to strengthen the structure. Then, the hot press process is to press the leaf layer using a pair of dies heated under controlled conditions (about 3 minutes). Then after the molding the plates is cut to trim the edges. The leaf plates were then sterilized using a sterilizer. Lastly, the packing process to send it to costumer.

\subsection{The Transformation}

The plates review process includes a group of young adult with a college academic back ground. This type of group is chosen as a representative of future Indonesian consumer behaviour. In the future Indonesia will have a demographic bonus as young and educated citizen will be the largest percentage of all Indonesian citizen[18]. They will assess the tebakak leaf plates using organoleptic approach in comparison of teak leaf plates, plastic plates, styrofoam plates and paper (paper with hdpe plastic lamination) plates. They will also be asked for their perspective of using the plates.

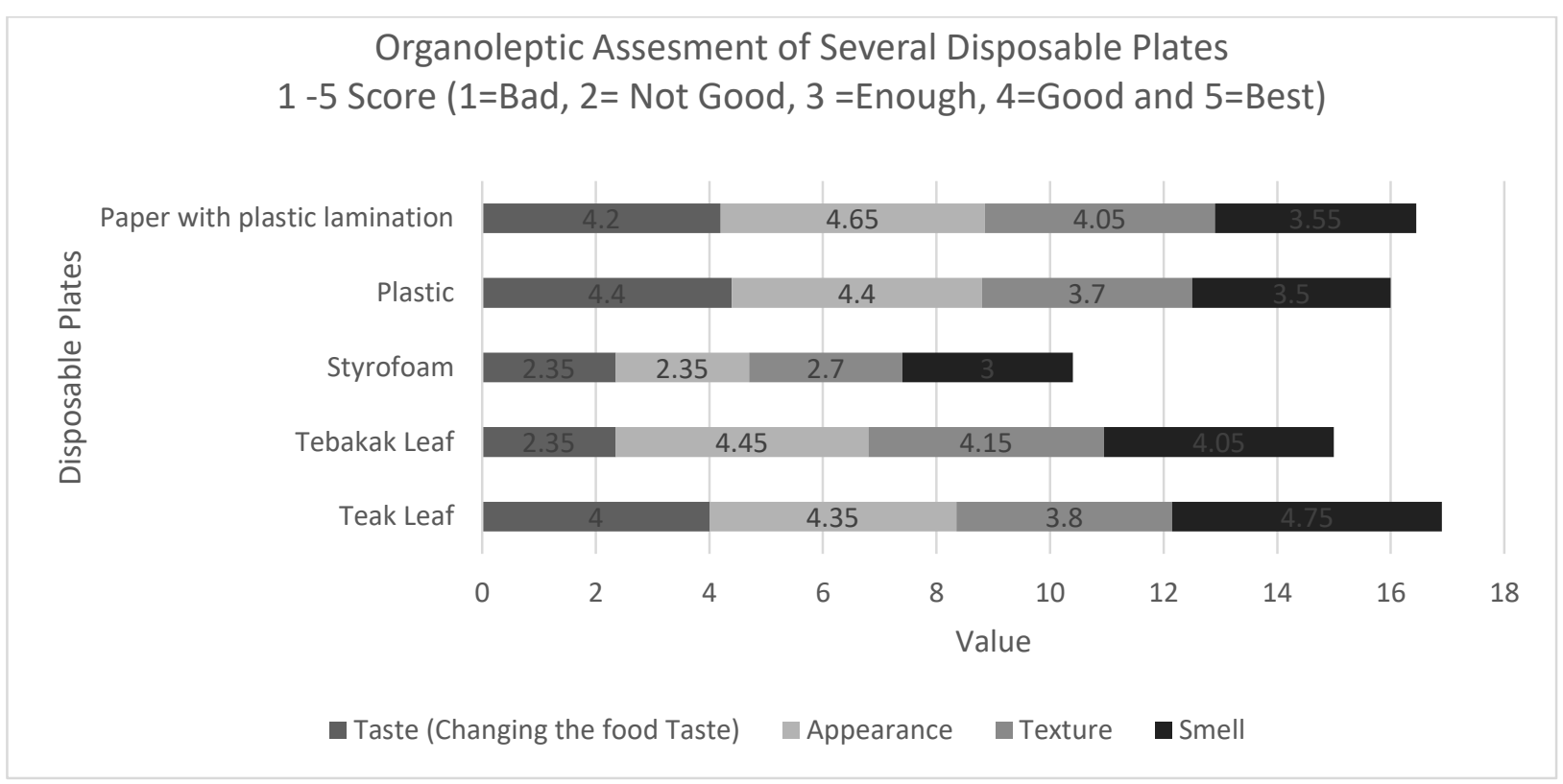

Figure 4. Organoleptic Assessment of Disposable Plates

Taste will become the enemy of leafy food container as shown on above figure because there are not as inert as the other disposable plates (plastic plates, styrofoam plates and paper plates). As the leaf when contact with food tends to alter the food taste. But this result can be view both ways (negatively or positively). Negatively, both of tebakak leaf plates and teak leaf plates can alter the food taste. But Positively, the altered taste might be just fine and not worsen the food taste. The argument also shown support on how the plates smell. Both leaf plates (tebakak and teak) smell quite nice better that other disposable plate (plastic plates, styrofoam plates 
and paper plates). As usually taste and smell tied positively in food. Form figure 4, we learn that both leaf plates (tebakak leaf plates and teak leaf plates) can be contender for plastic plates and paper plates while styrofoam plates has the lowest value.

\section{Perspective Assessment \\ 1 -5 Score (1=Bad, 2= Not Good, 3 =Enough, 4=Good and 5=Best)}
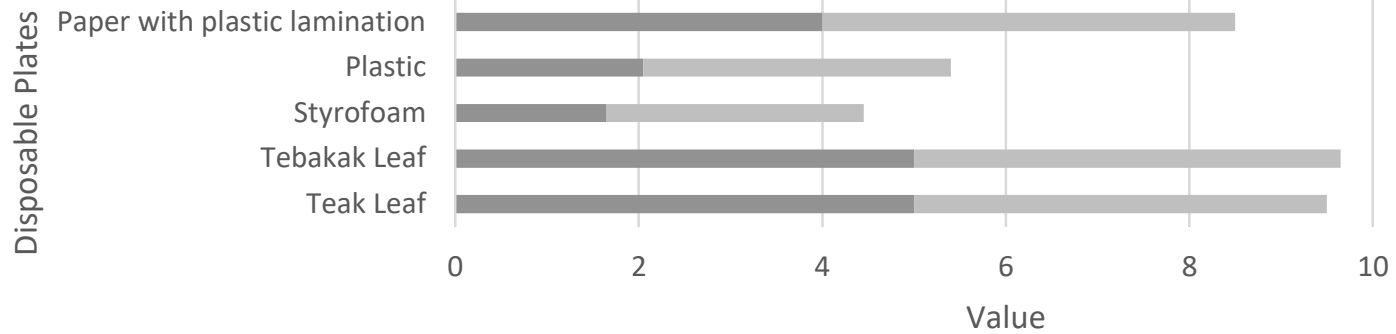

12

- Is It Green? Willingness for Using It

Figure 5. Perspective View on Disposable Plates

Perceptively there is no down arguments for how green is both for the tebakak leaf plates and the teak leaf plates. And the group also agrees that they want to use the tebakak leaf plates and the teak leaf plates. The main hindrance of using the plates is the availability on the market and its higher price. From Table 2. Product Comparison, we learn that the leaf plate machine capacity is quite low compared to other plates machine. If we can push the capacity of the leaf plate machine, then we can lower the leaf plate price and also flooding the market with plastic alternative product. More people will aware there are eco-friendly leaf plate products.
Total assessment form both test shown that future consumer tries to avoid styrofoam plates and plastic plates. And they agree that tebakak leaf plates, teak leaf plates and paper plates is best for them. In the end food taste changing by the leaf plates is not really a turn away for the consumer. The biggest challenge for the leaf pates is can we push the capacity of the leaf plate machine, if so then we can lower the leaf plate price and also flooding the market with plastic alternative product.

Table 2. Total Assessment

\begin{tabular}{|c|c|c|c|c|c|}
\hline \multicolumn{6}{|l|}{$\begin{array}{l}\text { Organoleptic and Perspective } \\
\text { Assessment }\end{array}$} \\
\hline & Teak leaf plate & $\begin{array}{l}\text { Tebakak leaf } \\
\text { plate }\end{array}$ & $\begin{array}{l}\text { Styrofoam } \\
\text { plate }\end{array}$ & $\begin{array}{l}\text { Plastic } \\
\text { plate }\end{array}$ & $\begin{array}{l}\text { Paper with } \\
\text { plastic } \\
\text { lamination } \\
\text { plate }\end{array}$ \\
\hline Taste (Changing the food Taste) & 4 & 2.35 & 2.35 & 4.4 & 4.2 \\
\hline Appearance & 4.35 & 4.45 & 2.35 & 4.4 & 4.65 \\
\hline Texture & 3.8 & 4.15 & 2.7 & 3.7 & 4.05 \\
\hline Smell & 4.75 & 4.05 & 3 & 3.5 & 3.55 \\
\hline Is It Green? & 5 & 5 & 1.65 & 2.05 & 4 \\
\hline Willingness for Using It & 4.5 & 4.65 & 2.8 & 3.35 & 4.5 \\
\hline Total & 4.4 & 4.1083333 & 2.475 & 3.567 & 4.1583 \\
\hline $\begin{array}{l}\text { 4. CONCLUSIONS } \\
\text { We learn that both leaf plates (te } \\
\text { and teak leaf plates) can be contender } \\
\text { and paper plates while styrofoam plat } \\
\text { value. And the group also agrees that te } \\
\text { and the teak leaf plates are green and }\end{array}$ & $\begin{array}{l}\text { akak leaf plates } \\
\text { for plastic plates } \\
\text { s has the lowest } \\
\text { bakak leaf plates } \\
\text { they want to use }\end{array}$ & \multicolumn{4}{|c|}{$\begin{array}{l}\text { availability on the market and its higher price. If we can } \\
\text { push the capacity of the leaf plate machine, then we can } \\
\text { lower the leaf plate price and also flooding the market } \\
\text { with plastic alternative product. Total assessment form } \\
\text { both tests shown that future consumer tries to avoid } \\
\text { styrofoam plates and plastic plates. And they agree that } \\
\text { tebakak leaf plates, teak leaf plates and paper plates is }\end{array}$} \\
\hline
\end{tabular}


best for them. In the end food taste changing by the leaf plates is not really a turn away for the consumer.

\section{ACKNOWLEDGMENTS}

We would like to give our gratitude to Mechatronics Laboratory and Metrology Laboratory in Mechanical Engineering department for their support in this research.

\section{REFERENCES}

[1] D. R. Haque, "Plastics: Wonder Material in Trouble," Paradigm, vol. 3, pp. 160-163, Jan. 1999.

[2] M. Yudell, D. Roberts, R. DeSalle, and S. Tishkoff, "NIH must confront the use of race in science," Science (80-. )., vol. 369, no. 6509, pp. 1314-1315, 2020.

[3] A. J. Kora, "Leaves as dining plates, food wraps and food packing material: Importance of renewable resources in Indian culture," Bull. Natl. Res. Cent., vol. 43, no. 1, 2019.

[4] R. Rini, Y. Fakhrurrozi, and D. Akbarini, "Pemanfaatan Daun Sebagai Pembungkus Makanan Tradisional Oleh Masyarakat Bangka (Studi Kasus di Kecamatan Merawang)," EKOTONIA J. Penelit. Biol. Bot. Zool. dan Mikrobiol., vol. 2, no. 1, pp. 20-32, 2018.

[5] Dawud Achroni, Belajar dari Makanan Tradisional Jawa. 2017.

[6] V. AC et al., "Global research priorities to mitigate plastic pollution impacts on marine wildlife ," Endanger. Species Res., vol. 25, no. 3, pp. 225-247, 2014.

[7] "Indonesia Consumers Are Most Pessimistic in 16 Years on Outbreak - Bloomberg." [Online]. Available:

https://www.bloomberg.com/news/articles/2021 -09-08/indonesia-consumers-are-mostpessimistic-in-16-years-on-outbreak. [Accessed: 20-Oct-2021].

[8] "Consumer Survey March 2021: Consumer Confidence Continues to Grow." [Online]. Available:

https://www.bi.go.id/en/publikasi/ruangmedia/news-release/Pages/sp_239121.aspx.

[Accessed: 20-Oct-2021].

[9] "Indonesia.go.id - Suku Bangsa." [Online]. Available: https://indonesia.go.id/profil/suku- bangsa/kebudayaan/suku-bangsa. [Accessed: 19-Oct-2021].

[10] "Suku Bangsa di Indonesia Sangat Beragam, Apa Penyebabnya? | kumparan.com.” [Online] Available: $\quad$ https://kumparan.com/beritaupdate/suku-bangsa-di-indonesia-sangatberagam-apa-penyebabnya-1v0EWRGG96x. [Accessed: 19-Oct-2021].

[11] R. Setiawan, "Memaknai Kuliner Tradisional diNusantara: Sebuah Tinjauan Etis Rudi Setiawan," Respons, vol. Gabriele W, no. 01, pp. 113-140, 2016.

[12] Y. Sari, B. Afriyansyah, and L. Juairiah, "Pemanfaatan Daun sebagai Bahan Pembungkus Makanan di Kabupaten Bangka Tengah," J. Peneletian Biol. Bot. Zool. dan Mikrobiol., vol. 04, no. 2, pp. 48-56, 2019.

[13] S. Sabana, "Nilai Estetis Pada Kemasan Makanan Tradisional Yogyakarta," ITB J. Vis. Art Des., vol. 1, no. 1, pp. 10-25, 2007.

[14] B. R. Noviadji, "Desain Kemasan Tradisional Dalam Konteks Kekinian,” Artika, vol. 1, no. 1, pp. 10-21, 2015.

[15] A. E. Nugroho, M. Ikawati, A. Hermawan, D D. P. Putri, and E. Meiyanto, "Cytotoxic effect of ethanolic extract fractions of Indonesia plant ficus septica Burm. F. On human breast cancer T47D cell lines," Int. J. Phytomedicine, vol. 3, no. 2, pp. 216-226, 2011.

[16] S. G. Kroeker, S. J. Bonin, A. L. DeMarco, C. A. Good, and G. P. Siegmund, "Age Does Not Affect the Material Properties of Expanded Polystyrene Liners in Field-Used Bicycle Helmets," J. Biomech. Eng., vol. 138, no. 4, Mar. 2016

[17] Martinus, A. Haryanto, S. Triono, and M. Telaumbanua, "Development of Teak Leaf Plate Molding Machine for Producing Plastic Alternative Products," Procedia Environ. Sci. Eng. Manag., 2021.

[18] "Indonesia's Demographic Dividend Reaches Peak in 2021." [Online]. Available: https://jakartaglobe.id/business/indonesiasdemographic-dividend-reaches-peak-in-2021. [Accessed: 20-Oct-2021]. 